DOI: $10.1515 /$ ausp-2015-0016

\title{
L2 Romanian Influence in the Acquisition of the English Passive by L1 Speakers of Hungarian
}

\author{
Enikő TANKÓ \\ Department of Humanities \\ Sapientia Hungarian University of Transylvania (Miercurea Ciuc, Romania) \\ tankoeniko@sapientia.siculorum.ro
}

\begin{abstract}
The main question to be investigated is to what extent native speakers of Hungarian understand and acquire the English passive voice, as there is no generalized syntactic passive construction in Hungarian. As we will show, native speakers of Hungarian tend to use the predicative verbal adverbial construction when translating English passive sentences, as this construction is the closest syntactic equivalent of the English passive voice. Another question to be investigated is whether L2 Romanian works as a facilitating factor in the process of acquiring the L3 English passive voice. If all our subjects, Hungarian students living in Romania, were Hungarian-Romanian bilinguals, it would be obvious that knowledge of Romanian helps them in acquiring the English passive. However, as it will be shown, the bilingualism hypothesis is disconfirmed. Still, passive knowledge of Romanian influences to some extent the acquisition of the English passive voice.
\end{abstract}

Keywords: passive, SLA, parameter resetting, L2/L3 influence

\section{Introduction}

This paper investigates the acquisition of the English passive voice by native speakers of Hungarian. Furthermore, it investigates the question whether L2 Romanian has any influence on the acquisition of the English passive voice. More specifically, the paper compares L2 or L3 English passive acquisition by learners who have contact with Romanian, a language which has a well-developed passive voice, and by learners from Hungary, who know no other language with a generalized passive voice.

The outline of the paper is as follows: the second section throws light upon the problems of expressing the passive meaning in Hungarian, the third part enunciates the main hypotheses, followed by the research methodology and the results of the experiment on the acquisition of the English passive voice by L1 
speakers of Hungarian. The paper ends with the conclusions based on the data of the empirical research.

\section{The problem}

There is a debate among specialists as to whether Hungarian does or does not possess a passive. Some linguists (see Siewierska 1984, MacWhinney, Pléh and Bates 1985, de Groot 1987, A. Jászó 2000, Kálmán 2001, among others) argue that there is no 'real' passive construction in Hungarian, others (e.g., Alberti 1996, 1998; Márkus 2008 and others) claim that the predicative verbal adverbial construction (henceforward PVAC) is a real passive construction. It is true that the PVAC resembles passivization in several respects: the internal argument is externalized, it contains an auxiliary (usually the existential verb) and the main verb undergoes certain morphological changes, losing its case assigning ability. Yet, as opposed to the English or Romanian passive constructions, the Hungarian PVAC has a low productivity due to numerous constraints. Furthermore, the agent can be overtly expressed only with the auxiliary lett/lesz 'become', which is quite infrequent.

Nevertheless, under the hypothesis that the PVAC is the closest equivalent ${ }^{1}$ of the English passive, we could have expected it to be described as a 'passive' in the grammars of Hungarian, since this is the case of the passive voice in English. Though it seems that the connection between the PVAC and passive meaning has been established for a long time, this point of view has not made its way in the official textbooks (cf. Keszler 1999, A. Jászó 2000, Kálmán 2001, among others).

Besides the PVAC, there are several other counterparts of the English passive which (partly) capture certain syntactic or discourse function properties of the English passive. Knowledge of these structures has activated certain parametric options assumably accessible during the acquisition of L2 English. These parametric options may be reset in the acquisition process. We were interested in to what extent the PVAC was given any preference by learners of English. This was interesting since, on the one hand, this construction is not described as a 'passive' form in Hungarian grammar, and on the other hand, it appears that there are significant dialectal differences in its use by different communities of Hungarian speakers (cf. Kádár and Németh 2010).

1 We use the term 'equivalent' or 'counterpart' for the structures which capture at least one (possibly all) of the properties of the English passive voice:

(i) the external argument is internalized, becoming a focused VP adjunct;

(ii) the internal argument is externalized;

(iii) the passive construction uses a special verb form (the proper Tense/Aspect form of the auxiliary and the past participle form of the main verb);

(iv) the passive is (almost) fully grammaticalized in English. 


\subsection{Equivalents of the English passive in Hungarian}

One of the counterparts of the English passive in Hungarian is the third person plural form of the verb in Present Tense which captures one of the main properties of the English passive construction. Namely, it has a generic reading, in which the agent is not expressed. Thus, in this respect, it resembles the English short passives.

(1) Megvizsgálják
PRT $_{\text {meg }}$ examine:3rd.pl
'They examine the child. / The child is examined.'

The example in (1) literally means 'They examine the child.', but it is more commonly meant like 'The child is examined.' This is shown by the fact that the above (third person plural) form can be used even when only one agent is meant (i.e. 'The child is examined by one doctor.').

Another Hungarian equivalent to be observed is the active sentence with the direct object in topic position in which the internal argument occupies sentence initial position.
A könyvet
becsomagoltam.
the book.ACC
'I have packed the book.'
${ }_{\text {PRT }}$ in .pack:1sg.past

As shown in (2), the active verbal form is not altered, and the external object is kept as the subject. Only the internal object moves in topic position. However, it retains the accusative case, as opposed to the passive voice in English. Thus, the active sentence with the direct object in topic position is an equivalent which resembles the English long passives.

The other active structure which corresponds to the English passive from an informational point of view is the active sentence with the direct object in topic- and the subject in focus position. Here the internal argument occupies the sentence's initial position, followed by the focused external argument.
(3) Ezt az autót
ÉDESAPÁM vásárolta.
this the car.ACC
father.my
buy.3sg.past
'This car has been bought by my father.'

Again, the active verbal form is not altered, and the external object is kept as the focused subject. Thus, the active sentence with the direct object in topic and the subject in focus position is a counterpart which resembles the English long passives where the agent is focused on, since it brings new information. 
The Hungarian $\mathrm{PVAC}^{2}$ is the closest structure, in characteristics, to the English or Romanian passive voice. It is formed with the auxiliary van 'to be' or lett/lesz 'become' and the adverbial participle form of the verb (ending in $-v A^{3}$ ).

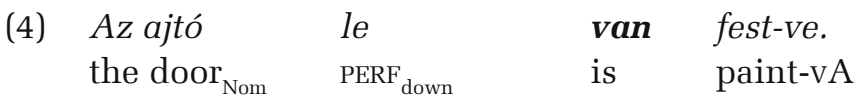
'The door has been painted.'

(5)
Az ajtó le
the door ${ }_{\text {Nom }} \quad$ PERF $_{\text {down }}$
lett
fest-ve tegnap.
became
paint-vA yesterday

'The door got painted yesterday.'

Though the English passive voice is (almost) fully grammaticalized, the Hungarian PVAC has several constraints. First of all, there are certain lexical constraints, related to the class of verbs which can appear in the construction. Only transitive verbs and unaccusatives are compatible with the PVAC, but not unergatives (see 6.a,b vs 6.c).

(6)
a. A kávé
meg
van
ôrölve.
the coffee PERF
be:3sg
grind-vA
'The coffee has been ground.'
b. A tó be
van
the lake
PERF $_{\text {in }}$
be:3sg
'The lake is frozen.'
c. * Mari énekelve van.
Mary sing-vA be:3sg
* 'Mary is sung.' (Kertész 2005: 2)
fagyva.
freeze-vA

Aspectual constraints on the PVAC are connected to telicity. Only telic verbs are compatible with the PVAC, that is accomplishments and achievements (see 7.c,d vs. states and activities in 7.a,b).

(7)
a. * Mari
szeretve
van.
Mary
love-vA
be:3sg
'Mary is loved.'
b. *Az eső zuhogva
van.
the rain
pour-vA
be:3sg

2 See Groot 1987, 1989; Komlósy 1994; Alberti 1996, 1998; Laczkó 1994, 1995, 2000, 2005; Tóth 2000; Bene 2005; Kertész 2005; Németh 2007; Bartos 2009; Márkus 2008, Tankó 2011.

3 The capital letters of the vowels signal that they have variable forms according to the vowel harmony: -va/-ve and -ván/-vén, the choice depends on the phonological properties of the vowels of the stem (Bartos 2009: 75). 
'The rain is pouring.'

$\begin{array}{lll}\text { c. A levél meg } & \text { van } & \text { írva. } \\ \text { the letter PERF } & \text { be:3sg } & \text { write-vA } \\ \text { 'The letter has been written.' } & \\ \begin{array}{llll}\text { d. Az üveg el van } & \text { pattanva. } \\ \text { the glass PERF } & \text { be:3sg } & \text { crack-vA }\end{array}\end{array}$

'The glass is cracked.' (Kertész 2005: 16-17)

Finally, syntactic constraints are connected with the presence/absence of an overtly expressed agent-phrase. Only the be-PVAC allows an overtly expressed agent (see 8.b). Consequently, only the be-PVAC allows event-related manner adverbs (as shown in 9.b).
a. *A fal le
van
fest-ve
a fiú
által. the wall PRT $_{\text {down }}$ is paint-vA
the boy
by 'The wall is painted by the boy.'
b. A fal
a fiú
által lett
lefestve. the wall.Nom the boy by become:3.sg.past ${ }_{\text {PERF }}$ down .paint-vA 'The wall has been painted by the boy.'
a. *A levél
gyorsan
van
meg-ír-va.
the letter
quickly
is
PERF -write-vA
'The letter is written quickly.'
b. A levél
gyorsan
lett
meg-ír-va.
the letter quickly
become
PERF -write-vA
'The letter got written in a hurry.' (Tóth 2000: 241-242)

Though the Hungarian PVAC is the closest syntactic equivalent of the English (or Romanian) passive, native speakers are not aware of the passive-like properties of the structure. This is due to not learning about the PVAC during Hungarian classes. On the other hand, in L2 or L3 acquisition of the English passive students have neither positive nor negative evidence for considering the PVAC the Hungarian counterpart of the English (or Romanian) passive. Consequently, when translating an English passive sentence, Hungarian learners of English have to choose from several equivalents of the passive which retain the characteristics of certain parameters, observing the discourse functions of the passive. Passive might be difficult on several levels: there might occur comprehension problems or problems in the formation of the passive (selection of appropriate auxiliaries, participial form, tense and aspect), but also problems related to the syntactic equivalent, namely which pattern is the closest structural equivalent of the English passive. 


\subsection{The status of L2 Romanian with the tested subjects}

L1 speakers of Hungarian from Transylvania learn Romanian passive structures (or at least learn about them) which are functionally and structurally very similar to the English passive constructions. However, students seem to make mistakes when using the passive, while in essays and other freely composed texts they tend to avoid using it. In an account for the facts one must check to what extent the respective Hungarian learners of English are indeed bilingual. ${ }^{4}$ One assumption is that Hungarians from Romania are bilingual, and as such, their knowledge of Romanian would be a facilitating factor in acquiring the English passive construction. Another hypothesis is that very few subjects of the mentioned group of speakers can be considered bilingual speakers of Hungarian and Romanian. In order to decide on the Romanian influence on native speakers of Hungarian from Miercurea Ciuc, we need to analyze the issue by looking first of all at the characteristics of the area of Miercurea Ciuc from a linguistic perspective, furthermore, we need to have a glimpse at the educational system.

In the Romanian education system Hungarian children start learning Romanian quite early, at the age of 3 , in kindergartens. They have about five Romanian activities every week. Later, in elementary school the situation is similar, children have four or five Romanian classes weekly. This would be fairly reasonable. However, in Romania there are certain geographic areas where Hungarians are in majority. In these regions Hungarian children do not speak Romanian in their homes. Furthermore, they have limited contact with Romanian. This is the case of Miercurea Ciuc (Csíkszereda in Hungarian), where over $80 \%$ of the population is Hungarian. ${ }^{5}$ The majority of the subjects from Miercurea Ciuc do not have 'nativelike control' of Romanian (cf. Bloomfield 1933) and they cannot 'interchangeably use' Romanian and Hungarian (cf. Mey 2009). As such, children with L1 Hungarian from the area above described can be considered, at most, receptive bilinguals (cf. Bhatia and Ritchie 2006).From the fifth grade (at the age of 11-12) children learn literature and grammar, but they do not have communication classes. Those children

4 Bilingualism is defined differently by different authors. Bilinguals are most commonly defined as individuals who have 'native-like control of two languages' (Bloomfield 1933: 56). Haugen (1953: 7) defines them as individuals who 'can produce complete meaningful utterances in the other language'. In the Concise Encyclopedia of Pragmatics we find the following definition: "The word 'bilingual' primarily describes someone with the possession of two languages. It can, however, also be taken to include the many people in the world who have varying degrees of proficiency in and interchangeably use three, four or even more languages." (Mey 2009: 38) Broader definitions of bilingualism focus on the daily use of two languages among bilinguals (Bhatia and Ritchie 2006: 115). Some authors make a distinction between receptive (or passive) bilingualism, and productive (or active) competence. Receptive bilinguals understand a language, but cannot produce it themselves (Bhatia and Ritchie 2006: 10).

5 According to the latest census (2011), the population of Miercurea Ciuc was of 37,980 inhabitants: 81.39\% Hungarian, $17.4 \%$ Romanian, $0.9 \%$ Romani and $0.33 \%$ other nationalities. See http:// en.wikipedia.org/wiki/Miercurea_Ciuc\#Demographics, last visited on 31 March, 2014. 
who have limited contact with native speakers of Romanian have difficulties in acquiring Romanian. The overwhelming number of the Hungarian children where the Hungarian population is in majority learn and use Romanian exclusively at school. Furthermore, they have limited contact with native speakers of Romanian. However, from the fifth grade children with L1 Hungarian are expected to know as much Romanian as their native speaker of Romanian colleagues, as they learn by the same curriculum. What is more, at the different exams they are expected to have the same level of Romanian. Under these circumstances it is quite difficult to learn the language properly during school hours.

Nevertheless, we must point out that subjects need not be bilingual in order to be influenced by Romanian to some extent. More exactly, even if students do not speak the language fluently, when they learn about the passive voice in Romanian, they become aware of the passive, as a grammatical category, in any case. They also have some exercises connected to recognizing and forming the Romanian passive constructions. Consequently, they get some idea about how passive structures function. This knowledge, no matter how poor or rich, might influence them later in the acquisition of the English passive voice.

\section{The hypotheses}

The primary aim of the experimental research is to investigate parameter setting in L2 English ${ }^{6}$ by speakers of Hungarian as L1, regarding the parameters of the passive / passive-like constructions. The first task is, thus, to correctly identify dimensions of parametric variation characterizing the English passive on the basis of which Hungarian speakers select an equivalent. On the other hand, it is not conceived of these as passive counterparts. The issue is even more important, as it provides evidence/ counterevidence for the hypotheses regarding the influence of the first language parameters on second language acquisition (White 2003). ${ }^{7}$

We will adopt the hypothesis that the mother tongue has influence on SLA. According to the Parameter Resetting Hypothesis (Finer and Broselow 1986; Finer 1990; MacLaughlin 1996, 1998), in the initial stages of SLA interlanguage grammars are impregnated by L1 parameters. Thus, L1 speakers of Hungarian

$6 \quad$ Note that English is actually the third language of most of the participants (i.e., subjects from Romania). However, for reasons of convenience, the term 'second language' (L2) is used throughout this study.

$7 \quad$ There are theories according to which only L1 parameter settings are exemplified in interlanguage grammars (Hawkins 1998; Hawkins and Chan 1997) and they cannot be reset (i.e., No Parameter Resetting Hypothesis). Others assume the contrary, namely that interlanguage grammars can realize parameter values distinct from those found in the L1, i.e., that parameters can be reset (Finer and Broselow 1986; Finer 1990; MacLaughlin 1996, 1998, among others). We will adopt this latter hypothesis of parameter resetting in L2. 
are expected to make mistakes, at least in the initial stages of learning English. However, in later stages, L2 learners adopt parameter values distinct from those found in their L1 (i.e., reset parameters). In our case, Hungarian learners of English will be expected to apply the parameters valid for the PVAC to the L2 English passive constructions (provided we accept that the Hungarian PVAC is the closest syntactic counterpart of the English passive).

Another point of interest represents seeing whether the subjects who know Romanian more or less will solve the test using approximately the same structures as the subjects from Hungary or there will emerge important differences. To put it differently, we want to test whether Romanian L2 influences English L3, thus facilitating access to the English passive. A further step in our research will be involving native speakers of Hungarian (also learning English) who have unlimited contact with Romanian, being able to use it not just at school, but in everyday life conversations as well. Comparing the result of the groups having different degrees of contact with Romanian will lead us to establish whether knowledge of Romanian really facilitates learning the English passive. Our hypothesis is that subjects from Romanian districts will have better results in the tests involving the English passive voice, as we believe there is transfer from L2 Romanian. As such, we expect that the group of subjects from Budapest, Hungary will make more mistakes when using the English passive.

Another issue to investigate is whether subjects will use the Hungarian PVAC when establishing a correspondent for an English passive sentence (even without being aware of the similarities between the two mentioned structures) or will resort to some other structure carrying the passive meaning. A further issue we shall look into is related to dialectal variations of Hungarian, namely whether the same constraints apply for the PVAC in the different dialects spoken by the subjects involved in our research (i.e., the dialect spoken in Budapest, in Miercurea Ciuc and in Braşov).

Summarizing, the main questions to be investigated in this research are the following:

1. Which parameters of the passive are activated / determine the selection of an equivalent?

2. To what extent preference is given to the closest syntactic equivalent (i.e., PVAC) rather than an equivalent which reflects only the discourse parameters of the passive?

3. Is there any dialectal variation in the acquisition of the passive by Hungarian speakers (differences due to the fact that they speak a slightly different variation of Hungarian, in contact with a third language (i.e., Romanian))? 


\section{Research methodology}

\subsection{Subjects}

Data has been provided by a number of 113 subjects grouped according to the three types of linguistic backgrounds. One group was that of tenth-graders and eleventh-graders attending different secondary schools in Miercurea Ciuc $(\mathrm{n}=48$, 17-18-year-olds, mean age: 17.3). There was a second group of tenth-graders ( $\mathrm{n}=43,16-17$-year-olds, mean age: 16.7) from a secondary school in Budapest, Hungary. A third group included 22 eleventh-grader subjects from Braşov, aged 17-19 (mean age: 18.1).

Respondents from Budapest and those from Braşov formed the control groups, as the former group lacked Romanian influence, the latter had unlimited contact with Romanian in everyday life. ${ }^{8}$ The group of students from Hungary had learnt only English as a foreign language, and as such could not be influenced by knowledge of any other languages regarding the passive structures. The two groups of respondents from Romania had learnt English two hours per week since third grade; the subjects from Hungary had learnt English since first grade.

Testing was conducted in Romania and Hungary; the subjects were recruited from several schools and tested during their English classes. In order to differentiate between the three distinct groups, we used abbreviations: $I M$ for learners from Miercurea Ciuc; $I B$ for students from Braşov; and $I H$ for respondents from Budapest, Hungary.

\subsection{The data}

Originally we have administered and analyzed several, more elaborate tests as part of a doctoral research, including rephrase and elicited production tasks, picture-identification and grammaticality judgement tasks. However, in this paper we will present only the data of two translation tasks.

\subsubsection{Translation from English into Hungarian}

Among the sentences to be translated, there were English passive sentences with and without an overtly expressed agent in the by-phrase, containing both progressive and non-progressive passive forms. In this task we wanted to find out which structures L1 speakers of Hungarian found to be the counterparts of the

8 According to the last Romanian census (2011), the population of Braşov was of 253,200 inhabitants: $91.3 \%$ Romanian, $7.1 \%$ Hungarian, $0.5 \%$ German, $0.4 \%$ Romani and $0.7 \%$ other ethnicities. See http://en.wikipedia.org/wiki/Bra\%C8\%99ov\#Demographics, last visited on 31 January, 2014. 
English passive. We expected respondents to use the PVAC whenever possible, though several other structures were available, each with certain constraints. The task was the following:

(10) Translate the following sentences into Hungarian.

$a$. The boy was visited by the doctor. -

$b$. The cat is called out by the little girl. -

c. The cat has been bitten by the dog. -

d. Tom was shown the dog by Mary. -

As Table 1 shows, even without being aware of the similarities between the Hungarian PVAC and the English passive, many subjects associate them in translation tasks.

Table 1. Results of the first translation task (E-H), given in percentages

\begin{tabular}{|c|c|c|c|c|c|}
\hline \multicolumn{2}{|c|}{ Translation } & \multirow{2}{*}{$\begin{array}{c}\begin{array}{c}\text { No } \\
\text { translation }\end{array} \\
10.40\end{array}$} & \multirow{2}{*}{$\begin{array}{c}\text { Active transl, } \\
\text { DO in topic } \\
6.30\end{array}$} & \multirow{2}{*}{$\begin{array}{c}\text { Transl. with } \\
\text { the PVAC }\end{array}$} & \multirow{2}{*}{$\begin{array}{c}\text { Regular } \\
\text { active transl. } \\
-\end{array}$} \\
\hline \multirow{3}{*}{ A } & IM & & & & \\
\hline & $\mathrm{IH}$ & 2.30 & 62.80 & 4.70 & 30.20 \\
\hline & IB & - & 9.00 & 90.90 & - \\
\hline \multirow{3}{*}{ B } & $\mathrm{IM}$ & 10.40 & 8.30 & 81.30 & - \\
\hline & $\mathrm{IH}$ & 2.30 & 62.80 & 2.30 & 32.60 \\
\hline & IB & 4.54 & 9.00 & 81.80 & 4.54 \\
\hline \multirow{3}{*}{ C } & $\mathrm{IM}$ & 10.40 & 12.50 & 77.10 & - \\
\hline & $\mathrm{IH}$ & 2.30 & 67.40 & 2.30 & 27.90 \\
\hline & IB & - & 9.00 & 86.30 & 4.54 \\
\hline \multirow{3}{*}{$\mathrm{D}$} & $\mathrm{IM}$ & 10.40 & 12.50 & 77.10 & - \\
\hline & $\mathrm{IH}$ & 2.30 & 46.50 & 16.30 & 34.90 \\
\hline & IB & 4.54 & 9.00 & 77.20 & 9.00 \\
\hline \multirow{3}{*}{ TOTAL } & IM & 10.41 & 9.89 & 79.68 & - \\
\hline & IH & 2.32 & 59.88 & 6.39 & 31.39 \\
\hline & IB & 2.27 & 9.00 & 84.05 & 4.50 \\
\hline
\end{tabular}

A considerable number of respondents from Romania (79.68\% (IM) and 84.05\% (IB), as compared to $6.39 \%(\mathrm{IH})$ ), regardless of the school attended, resorted to PVAC. Interestingly, according to contemporary standard Hungarian, this type of construction is incompatible with the verbs from the first three sentences (i.e., the verb class is not compatible with the PVAC, since only telic verbs with affected object can enter the structure).

Though the presence of the overtly expressed agent is ruled out in the PVAC with the be-PVAC, Romanian respondents still resorted to this translation equivalent in the 
first two sentences. Furthermore, they used the PVAC with the existential auxiliary with verbs that normally are not allowed with this type of construction (e.g., atelic verbs, like hív 'call' in or verbs with non-affected direct object, like látogat 'visit').

The subjects from Hungary chose active sentences with the direct object in topic position when translating the same sentences $(59.88 \%(\mathrm{IH})$, as compared to $9.89 \%$ (IM) and $9 \%$ (IB)). On the one hand, we could think that this is because of the Romanian influence, but, on the other hand, this could be due to dialectal variations as well.

In a study regarding the differences between the PVAC in contemporary standard Hungarian vs. in the Csángó dialect, ${ }^{9}$ Kádár and Németh (2010) notice that the number of occurrences of the structure differ significantly. "The database of approx. 160 million words of the HNC [Hungarian National Corpus - our remark] gives a hit list of 13,674 entries for VAN + V-vA (date of query: spring 2005). This means that while in the Csángó texts [a corpus of 537,061 words - our remark] we find a PCC for every 365 word, in the HNC it is only for every 11,700 word that a PPC occurs. This frequency index supports the conclusion that the use and function of the PPC in the Csángó dialect is wider than it is in standard Hungarian" (Kádár, Németh 2010: 201).

It seems that the PVAC is not just more frequent in the Csángó dialect, but it is less constrained, as compared to standard Hungarian. The most important differences concern the type of verbs which enter the structure, as well as their aspectual class. While in standard Hungarian unergative verbs cannot enter the PVAC, the Csángó dialect is more permissive (as in 11). Furthermore, in standard Hungarian only telic verbs with affected object can be used in the PVAC, yet in the Csángó dialect atelic verbs are acceptable as well (see 12 below).
... a férje
el
volt
futva
hazulnét.
the husband-Poss.3SG
$\mathrm{PV}_{\text {away }}$
was run-vA
from.home

'...her husband was (=has) run away from home.'

(12)

$\begin{array}{llll}\ldots . . m e g k e ́ r d t e ́ k & \text { merrefelé } & \text { vagyunk } & \text { utazva... } \\ \mathrm{Pv}_{\mathrm{meg}} \text {-asked-3PL } & \text { whereabout } & \text { are-1PL } & \text { travel-vA }\end{array}$

'...they’ve asked where we were travelling to...' (Kádár \& Németh, 2010: 204)

Another difference concerns the presence of an oblique agent. In standard Hungarian, the presence of an overt agent is not allowed in constructions with

9 The Csángó people (Romanian: ceangăi, Hungarian: csángók) are a Hungarian ethnographic group of Roman Catholic faith living mostly in the Romanian region of Moldova, especially in Bacău county. Their traditional language, Csángó, an old Hungarian dialect is still in use, though the larger part of them speaks Romanian. For further information, see also http://en.wikipedia. org/wiki/Csangos, last visited on 31 March, 2014. 
the auxiliary van 'be' (as opposed to the lett/lesz 'become' auxiliary). The Csángó dialect is more permissive in this respect, too, allowing the agent-phrase with the be-PVAC (see 13).

(13) Akár hogy es tólem nincsen soha elfelejtve.
any how also from.1SG is.not never $\mathrm{Pv}_{\text {away }}$.forget-vA
'Anyway, I never forget that (lit. It is never forgotten by me).' (Ibid., 206)

Finally, the eventive reading of the PVAC is only possible with the auxiliary lett/lesz 'become' in standard Hungarian. Yet, the Csángós use the PVAC with the auxiliary van 'be' for eventive reading (as illustrated in 14).

Mikor meg volt halva Magda, erös szépen álmodtamakkor. when part ${ }_{\text {meg }}$ was die-vA Magda strong beautifully dreamed.1SG then 'When Magda died I had a very beautiful dream.' (Ibid. 209)

Returning to the data of our experiment, we could assume that there are some differences between standard Hungarian and the dialect spoken by Hungarians from Transylvania, possibly due to Romanian influence. Similarly to the Csángó dialect, in the dialects spoken in Transylvania, the PVAC seems more frequent and less constrained, as compared to the dialect spoken in Budapest. This could explain why respondents from Romania, mostly resorted to PVAC even in cases when they were not expected to, according to contemporary standard Hungarian. Since Romanian speakers are closer to the Csángó dialect, as compared to $\mathrm{IH}$ speakers, the same differences occurred in their production data. Namely, they extended the domain of the PVAC to unergatives, furthermore, they used the byphrase in sentences exhibiting the be-PVAC. In what follows, let us have a look at the Hungarian sentences provided by the two groups of respondents.

As already mentioned, there is a tendency in choosing from the available equivalents for the English passives; namely respondents from Romania tend to choose the PVAC (see 15.c, 16.c, 17.b and 18.b), though in most of the cases erroneously, while subjects from Hungary tend to use a translation with a sentence containing an active verb (as in 15.a, 16.a and 17.a), in the majority of the cases with the direct object in the topic position (illustrated in 15.b, 16.b and 17.a).

(15) The boy was visited by the doctor.

a. Az orvos meglátogatta a fiút. (neutral active sentence) the doctor.Nom prt $_{\text {meg }}$.visit.past.3.sg the boy.Acc

b. A fiút meglátogatta az orvos. (active sentence, DO in topic) the boy.Acc prt $_{\text {meg }}$.visit.past.3.sg the doctor.Nom 
c. *A fiú meg volt látogatva az orvos által. (PVAC) the boy.Nom prt $_{\text {meg }}$ be/become.past.3.sg visit.vA the doctor by

(16) The cat is called out by the little girl.
a. A kislány kihívta
a macskát. (neutral active sentence) the little.girl.Nom prt $_{\text {OUT }}$.call.past.3.sg the cat.Acc
b. A macskát hívta ki a kislány. (active sentence, DO in topic) the cat.Acc call.past.3.sg prt $_{\text {OUT }}$ the little.girl.Nom
c. \% A macska a kislány által lett/?van
kihívva. (PVAC)
the cat.Nom the little.girl by become/be.past.3.sg prt $_{\text {our }}$.call.vA

(17) The cat has been bitten by the dog.
a. A macskát megharapta a kutya. (active sentence with the DO in topic) the cat.Acc prt $_{\text {meg }}$.bite.past.3.sg the dog.Nom
b. ???A cica the cat.Nom meg lett harapva a kutya által. (PVAC) prt $_{\text {meg }}$ become.past.3.sg bite.vA the dog by

Based on these results, we can say that subjects from Romania mostly used the PVAC (which resembles the most the English passive) when translating an English passive sentence, though in certain cases, the translation with the PVAC was not even acceptable, as compared to standard Hungarian, since the verb was not compatible with the PVAC due to aspectual constraints. It seems that respondents put aside all constraints and still used the PVAC, as it seemed the closest structure to the English passive. Note that among all the translations with the Hungarian PVAC in this task, only the sentence in (16.c) is acceptable according to contemporary standard Hungarian.

In sum, subjects identified two translation equivalents for the passive sentences in English, namely the active sentence with the direct object in topic position (chosen mostly by IH respondents) and the PVAC (chosen mostly by IM and IB subjects). It seems that even without being aware of the similarities between the Hungarian PVAC and the English passive, many IM and IB subjects associate them in translation tasks. This could be due to Romanian influence. As mentioned at the beginning of this chapter, subjects need not be bilingual in order to be influenced by Romanian to some extent. Even if they do not speak the language fluently, when they learn about the passive voice in Romanian, they become aware of the passive as a grammatical category and they get some idea about how passive structures function. This knowledge, no matter how poor or rich, might influence them later in the acquisition of the English passive voice. 


\subsubsection{Translation from Hungarian into English}

In the second translation task we asked the respondents to translate four sentences: three exhibiting the PVAC and one active sentence with the direct object in topic position to be translated into English in order to ascertain to what extent there is equivalence between PVAC and the passive in English:

(18) a) Az ablak

be van

törve.

the window.Nom prt $_{\mathrm{IN}}$ be:3sg.present break.adv.part 'The window has been broken.'

$\begin{array}{llll}\text { b) A kutya } & \text { el } & \text { van } & \text { veszve. } \\ \text { the dog.Nom } & \text { prt }_{\mathrm{AWAY}} & \text { be:3sg.present } & \text { lose.adv.part }\end{array}$ 'The dog has been lost.'
c) Anna
magyart
tanított
Palinak.
Anne.Nom
Hungarian.Acc
teach:3sg.past
Paul.to

'Anne taught Hungarian to Paul.'
d) Az asztal
tele van
rakva
könyvekkel.
the table.Nom full be:3sg.present put.adv.part books.with

'The table is loaded with books.'

When translating the Hungarian sentences into English, we expect subjects to resort to different translation strategies. We expect them to provide passive translation for the sentences exhibiting the PVAC and active translation for the active sentence with the DO in topic (i.e., 18.c). PVAC is expected to be associated with passive sentences in English, as it is its closest syntactic equivalent (it disposes of a special verbal phrase, it selects the internal argument as subject, it implies an auxiliary and it may or may not overtly express the agent). Consequently, we expect that L1 Hungarian will influence the respondents' interlanguage grammar, thus they will resort to a passive construction when translating a Hungarian PVAC.

Table 2. Results of the second translation task (H-E), given in percentages

\begin{tabular}{lccccc}
\hline \multicolumn{2}{c}{ Translation } & $\begin{array}{c}\text { No } \\
\text { translation }\end{array}$ & $\begin{array}{c}\text { Active } \\
\text { translation }\end{array}$ & $\begin{array}{c}\text { Passive } \\
\text { translation }\end{array}$ & $\begin{array}{c}\text { Passive, problems } \\
\text { (aux/tense/asp) }\end{array}$ \\
\hline $\mathrm{A}$ & $\mathrm{IH}$ & 2.30 & 11.60 & 67.40 & 18.60 \\
\cline { 2 - 6 } & IM & 12.50 & 8.30 & 79.20 & - \\
\cline { 2 - 6 } & IB & - & - & 54.50 & 45.50 \\
\hline $\mathrm{B}$ & $\mathrm{IH}$ & 2.30 & 9.30 & 58.10 & 30.20 \\
\cline { 2 - 6 } & IM & 12.50 & 14.60 & 72.90 & - \\
& IB & - & - & 63.60 & 36.30 \\
\hline
\end{tabular}




\begin{tabular}{llcccc}
\hline \multicolumn{2}{l}{ Translation } & $\begin{array}{c}\text { No } \\
\text { translation }\end{array}$ & $\begin{array}{c}\text { Active } \\
\text { translation }\end{array}$ & $\begin{array}{c}\text { Passive } \\
\text { translation }\end{array}$ & $\begin{array}{c}\text { Passive, problems } \\
\text { (aux/tense/asp) }\end{array}$ \\
\hline $\mathrm{C}$ & IH & 2.30 & 53.50 & 20.90 & 23.30 \\
\cline { 2 - 6 } & IM & 12.50 & 25.00 & 60.40 & 2.10 \\
\cline { 2 - 6 } & IB & - & 63.60 & 4.54 & 31.64 \\
\hline \multirow{2}{*}{$\mathrm{I}$} & IH & 2.30 & 46.50 & 27.90 & 23.30 \\
\cline { 2 - 6 } & IM & 12.50 & 16.70 & 70.80 & - \\
\cline { 2 - 6 } & IB & - & 40.90 & 22.70 & 36.10 \\
\hline \multirow{2}{*}{ Total } & IH & $\mathbf{2 . 3 2}$ & $\mathbf{3 0 . 2 3}$ & $\mathbf{4 3 . 6 0}$ & $\mathbf{2 3 . 8 3}$ \\
\cline { 2 - 6 } & IM & $\mathbf{1 2 . 5 0}$ & $\mathbf{1 6 . 1 4}$ & $\mathbf{7 0 . 8 3}$ & $\mathbf{0 . 5 2}$ \\
\cline { 2 - 6 } & IB & - & $\mathbf{2 6 . 0 7}$ & $\mathbf{3 6 . 3 3}$ & $\mathbf{3 7 . 3 8}$ \\
\hline
\end{tabular}

Table 2 provides a list of frequency of the constructions used in translation. Most students used a passive structure when translating the Hungarian sentences into English, though the percentages slightly differ. Interestingly, in the case of sentences $(18 . a, b)$ the majority of both groups translated the PVAC with an English passive structure. In the case of sentences (18.c,d) around half of the respondents from Hungary (53.5\% and $46.5 \%$ ) provided active sentences in the translation, though only sentence (18.c) was active. The majority of respondents from Romania chose the passive translation in case of sentences (18.c,d) as well.

In the first two sentences to be translated in this task (18.a,b), we had two PVACs, both with the auxilary van 'be'. As the closest English equivalent of the Hungarian PVAC is the passive voice, it was expected that the majority of respondents would use passive voice in translating these sentences.

Only $11.6 \%$ and $9.3 \%$ of the respondents from Hungary, respectively $8.3 \%$ and $14.6 \%$ of the IM subjects provided translations in the active vs. none of the IB respondents. $86 \%$ and $88.3 \%$ of the IH students, respectively $79.2 \%$ and $72.9 \%$ of the IM respondents used the passive voice as opposed to $100 \%$ of the IB subjects. An ANOVA test on these data reveals that the difference between IM and $\mathrm{IH}$ subjects is statistically significant, $\mathrm{p}<0.001$.

As expected, there occurred minor mistakes connected to passive morphology (18.6\% , respectively $30.2 \%$ of the IH respondents and $45.5 \%$, respectively $36.6 \%$ of the IB subjects failed in maintaining the proper tense and aspect or provided an erroneous participial form, as in 19.a,b or 20.a,b).

(19) Az ablak

the window.Nom be

$\operatorname{prt}_{\mathrm{IN}}$ törve. break.adv.part

'The window has been broken.'

a. *The window is broked.

b. *The window was broke. 

(20) A kutya
el
van
veszve. (PVAC)
the dog.Nom prt $_{\text {AWAY }}$
be:3sg.present
lose.adv.part
'The dog has been lost.'
a. ${ }^{*}$ The dog is losed.
b. *The dog is losted.

However, we are not interested in mistakes connected alone to passive morphology, as these type of mistakes are not characteristic for Hungarian learners. As shown by Pinker, Lebeaux and Frost's (1987) experiment, among others, even native speakers of English make mistakes in providing the correct past participle forms.

From an SLA point of view, a much more intriguing problem is that of translating sentence (18.c) into English. Though the given Hungarian sentence contains an active verb form, its direct object is in topic position. Probably this topic position influenced some of the subjects in choosing a passive equivalent for this sentence ( $44.2 \%$ (IH), $62.5 \%$ (IM) and $35.2 \%$ (IB), as in 21.c). Still, $53.5 \%$ of the subjects from Budapest provided active sentences (e.g., 21.a,b), while only a quarter of the IM students did so. A possible explanation for providing a passive equivalent for the active sentence in 21 would be that respondents overgeneralize in providing passive equivalents for each Hungarian sentence. After a series of tasks connected to the passive voice, they might have thought that passive was the correct answer in each case.

(21) Anna magyart tanított Palinak. (active sent., DO in topic)

Anne.Nom Hungarian.Acc teach:3sg.past Paul.to

'Anne taught Hungarian to Paul.'

a. Anna taught Hungarian to Paul.

b. Anna taught Pali Hungarian.

c. Pali was taught Hungarian by Anna.

d. *Anna teached Hungarian to Paul.

e. *Pali was teach Hungarian by Anna.

In case of this sentence, as well, mistakes connected to passive morphology occurred (as in 21.d,e). However, we will not insist on them, but go on to discussing the last sentence of this task. Sentence (18.d), repeated in 22, contains a PVAC with the auxilary van 'be', just like the first two sentences in this task. As such, we expected the same translation strategy to be applied (i.e., respondents choose a passive equivalent this time, as well). Yet, this did not happen in both groups. About half of the subjects from Hungary $(46.5 \%)$ and $40.9 \%$ of the IB subjects provided an active sentence (as in $22 . \mathrm{a}$ ), while only $16.7 \%$ of the respondents from Miercurea Ciuc did the same. In turn, around $65 \%$ of the students from 
Romania and $51.2 \%$ of those from Hungary chose the passive voice as the English equivalent for the Hungarian PVAC, as in 22.b, though sometimes minor mistakes occurred (as in 22.c). An ANOVA test on these data reveals that the difference between IM and IH subjects is statistically significant, $\mathrm{p}<0.001$.

(22)

$\begin{array}{ll}\text { Az asztal tele van } & \text { rakva könyvekkel. (PVAC) } \\ \text { the table.Nom full be:3sg.present } & \text { put.adv.part books.with } \\ \text { 'The table is full of books.' } & \end{array}$

a. The desk is full of books.

$b$. The table is loaded with books.

c. ${ }^{*}$ The table is put full by books.

Concluding, we must remark that the majority of the subjects involved in the experiment used the passive voice when translating the Hungarian PVAC into English. However, when it came to translating a Hungarian active sentence with the direct object in topic, subjects from Hungary mostly resorted to active translation equivalents. The most common mistake observed in the sentences provided by the respondents was connected to passive morphology. However, this type of mistake is not characteristic for Hungarian learners, but it can be found in the case of young native speakers as well (see Pinker, Lebeaux and Frost 1987).

\subsection{Discussions}

If we compare the sentences provided by the three groups of subjects (i.e., IH, IM and IB), we notice that respondents from Hungary tend to use active sentences with the direct object in topic, as counterparts of English passive sentences, while respondents from Romania (both from Miercurea Ciuc and Braşov) use the Hungarian PVAC more frequently when translating an English passive sentence.

A possible solution could be connected to differences between standard Hungarian and its dialects, as referred to by Kádár and Németh (2010). Their discussion of the differences between the PVAC in contemporary standard Hungarian vs. in the Csángó dialect points out three very important differences:

(i) The PVAC is much more frequent in the corpus of the Csángó dialect than in the database of standard Hungarian (Kádár, Németh 2010: 201).

(ii) In standard Hungarian the PVAC has more constraints, e.g., constraints on the class of the input verb, on its telic/atelic nature and affectef/non-affected DO, and on the appearance of an oblique agent (see Kádár and Németh 2010 for the Csángó dialect).

(iii) The Csángó dialect shows the influence of Romanian. ${ }^{10}$

10 "The geographical dispersion of the Csángó settlements and their relative isolation resulted in a non-homogeneous language. The oldest sub-dialect, northern Csángó, preserves numerous 
Firstly, based on the above enumerated information, we could imply that in the dialect spoken in Romania (i.e., the Székely dialect), too, the PVAC is more frequent than in the dialect spoken in Budapest. As such, respondents from Romania feel more free in using it as the equivalent of the English passive. That would explain the differences between the results of respondents from Budapest and those from Romania.

Secondly, under the hypothesis that in the dialects spoken in Trasylvania the PVAC has fewer constraints, we could explain why a considerable number of respondents used the PVAC with input verbs that were not compatible with the structure according to standard Hungarian, (see 23 below).

(23) \%A számítógép

the computer.Nom gyakran

often van

be.pres.3.sg használva. (PVAC)

use.vA

'The computer is used frequently.'

Thirdly, based on the findings of Kádár and Németh (2010) regarding the Csángó dialect, we must take Romanian influence into account, as a facilitating factor in the acquisition of the English passive voice by native speakers of Hungarian from Braşov. Being bilingual speakers of Hungarian-Romanian, they more easily identify the Hungarian equivalent which fits best the English passive construction. Namely, they resort to the PVAC when translating a passive construction, since the PVAC is the closest syntactic equivalent of the passive in English or Romanian.

Though the majority of students from Miercurea Ciuc cannot be considered bilingual speakers, it seems that Romanian still influences them to some extent. In other words, even if students do not speak fluent Romanian, they become aware of the passive, as a grammatical category, once they learn about the passive voice in Romanian. Consequently, they get some idea about how passive structures function and this influences them later, in the acquisition of the English passive voice. This is why the majority of respondents from Miercurea Ciuc resorted to the PVAC when looking for a counterpart of the English passive. In contrast, students from Hungary, first of all, have to deal with understanding the grammatical category of (passive) voice. This is why the majority of respondents from Budapest chose an active sentence with the direct object in topic when looking for an equivalent of the English passive.

elements of the Hungarian language of the late Middle Ages. The southern Csángó and SzékelyCsángó sub-dialects are less archaic, and all sub-dialects show the influence of Romanian, specific to that language area." (Kádár, Németh 2010: 200) 


\section{Conclusions}

Comparing the production data of respondents with different language background, we saw that respondents from Hungary mostly used active sentences with the direct object in topic, as counterparts of English passive sentences, while respondents from Romania (both from Miercurea Ciuc and Braşov) used the Hungarian PVAC more frequently when translating an English passive sentence.

The explanation is connected to differences between standard Hungarian and its dialects. It seems that in the dialect spoken in Transylvania the PVAC is more frequent and has fewer constraints than in the dialect spoken in Budapest. As such, respondents from Romania feel more free in using it as the equivalent of the English passive. This could be due to Romanian influence which works as a facilitating factor in the acquisition of the English passive voice by Hungarian students from Romania. Being bilingual speakers of Hungarian-Romanian, subjects from Braşov identified more easily the Hungarian equivalent which fitted best the English passive construction. Namely, they resorted to the PVAC when translating a passive construction, since the PVAC is the closest syntactic equivalent of the passive in English or Romanian. In contrast, the majority of respondents from Budapest chose an active sentence with the direct object in topic when looking for an equivalent of the English passive.

As shown in the study, the presence of an overtly expressed agent was an important operator in the process of providing Hungarian equivalents for the English passive sentences. The majority of the subjects used active sentences with the direct object in topic position when translating long passives, in contrast, they resorted to the PVAC when it came to translating short passives. Consequently, the presence of an overt agent does not make native speakers of Hungarian use the second type of PVAC with the auxiliary lett/lesz 'become' which would allow the agent-phrase, as we would have expected.

We have analysed the results of each test using the SPSS 14 software for checking statistical significance. In the case of the translation tasks where subjects had to translate Hungarian sentences into English, the differences between the groups of learners were statistically fully/marginally significant. In case of the translation tasks where subjects had to translate English sentences into Hungarian, we did not get statistically significant results. 


\section{References}

Adamikné Jászó, Anna. 2000. A magyar nyelv könyve [The Book of Hungarian Grammar]. Budapest: Trezor.

Alberti, Gábor. 1996. Model Tau: A Formal Theory of Thematic Roles. In Bánréti, Zoltán (ed.), Papers in the Theory of Grammar, 184-235. Budapest: Institute for Linguistics, Academy Press.

Alberti, Gábor. 1998. On Passivization in Hungarian. In Groot, Casper de \& Kenesei, István (eds.), Papers fom the Amsterdam Conference. Approaches to Hungarian (6): 105-121, Szeged: JATE Press.

Bartos, Huba. 2009. The syntax of Hungarian va- adverbial participles. A single affix with variable merge-in locations. In É. Kiss, Katalin (ed.), Adverbs and Adverbial Adjuncts at the Interfaces, 75-102, Berlin: Mouton de Gruyter.

Bene, Annamária. 2005. Az igék bennható-mediális-tranzitív felosztásának alkalmazhatósága magyar szintaktikai és morfológiai sajátosságok magyarázatában [The applicability of the unergative-unaccusative - transitive categorization of verbs in explaining syntactic and morphological properties of Hungarian]. PhD dissertation, Budapest: Eötvös Lóránd University.

Bhatia, Tej \& Ritchie, William. 2006. The Handbook of Bilingualism. Malden, Oxford, Carlton: Blackwell Publishing.

Bloomfield, Leonard. 1933. Language. New York: Holt.

Doughty, Catherine J. \& Long, Michael H. 2003. The Handbook of Second Language Acquisition, Malden, Oxford, Carlton: Blackwell Publishing.

É. Kiss, Katalin. 2008. Topic and focus: Two structural positions associated with logical functions in the left periphery of the Hungarian sentence. Acta Linguistica Hungarica 55: 287-296.

Finer, Daniel. 1990. Modularity and Lexical Parameterization in the Adult Grammar. Linguistics 28: 905-927.

Finer, Daniel \& Broselow, Ellen. 1986. Second Language Acquisition of Reflexive Binding. North Eastern Linguistic Society 16: 154-168.

Fox, Danny \& Grodzinsky, Yosef. 1998. Children's passive: a view from the byphrase. Linguistic Inquiry 29: 311-332.

Groot, Casper de. 1987. On the predicative verbal adverbial construction in Hungarian. In Kenesei, István (ed.), Approaches to Hungarian 2: 273-298, Szeged: JATE Press.

Groot, Casper de. 1989. Predicate Structure in a Functional Grammar of Hungarian: Functional Grammar Series (11). Dordrecht: Foris Publications.

Haugen, Einar. 1953. The Norwegian Language in America: A Study in Bilingual Behaviour, Philadelphia: University of Pennsylvania Press. 
Hawkins, Roger. 1998. The inaccessibility of formal features of functional categories. Second language acquisition, Paper presented at the Pacific Second Language Research Forum, Tokyo.

Hawkins, Roger \& Chan, Yuet-Hung Cecilia. 1997. The partial availability of Universal Grammar in second language acquisition: the 'failed functional features hypothesis'. Second Language Research 13: 187-226.

Kádár, Edit \& Németh, Boglárka. 2009. Predikatív határozói igeneves szerkezetek Csángó beszélt nyelvi szövegekben [The predicative verbal-adverbial constructions in the Csángó spoken texts]. In É. Kiss Katalin and Hegedús Attila (eds.), Nyelvelmélet és dialektológia [Language Theory and Dialectology], 189212. Piliscsaba: Pázmány Péter Katolikus Egyetem.

Kádár, Edit \& Németh, Boglárka. 2010. The role of the predicative participle construction in the Csángó tense-aspect system. Philobiblon 15: 194-225.

Kálmán, László. 2001. Magyar leíró nyelvtan [Hungarian descriptive grammar]. Budapest: MTA.

Kertész, Judit. 2005. Eseményszerkezet, aspektus, mondatszerkezet. A predikatív határozói igenevek [Event structure, aspect, clause structure: The predicative adverbial participles]. PhD dissertation. Budapest: Eötvös Lóránd University.

Keszler, Borbála. 1999. Magyar grammatika [Hungarian Grammar]. Budapest: Nemzeti.

Komlósy, András. 1994. Complements and Adjuncts. In Kiefer, Ferenc \& É. Kiss, Katalin (eds.), Syntax and Semantics, vol. 27, The Syntactical Structure of Hungarian, 91-178. San Diego - New York: Academic Press.

Laczkó, Tibor. 1993. Unaccusative Participles in Hungarian and the Theory of Lexical Mapping: Proceedings of the 4th Symposium on Logic and Language, 149-163. Budapest: Áron Publishers.

Laczkó, Tibor. 1994. On a "Passive" Participle in Hungarian. Proceedings of the Fourth Colloquium on Generative Grammar 16, Tarragona.

Laczkó, Tibor. 1995. The Syntax of Hungarian Noun Phrases. A Lexical-Functional Approach. Frankfurt: Peter Lang.

Laczkó, Tibor. 2000. A melléknévi és határozói igenévképzők [The adjectival and adverbial participial affixes]. In Kiefer Ferec (ed.), Strukturális magyar nyelvtan, Morfológia [A structural grammar of Hungarian, 3. Morphology], 409-451, Budapest: Academy Press.

Laczkó, Tibor. 2005. Nominalization, participle formation, typology, and lexical mapping theory. In Piñon, Christopher \& Siptár, Péter (eds.), Approaches to Hungarian, 9. Papers from the Düsseldorf Conference, 207-230, Academic Press, Budapest.

Márkus, Andrea. 2008. Participles and the passive in Hungarian. MA thesis, Budapest: Eötvös Lóránd University. 
Mey, Jacob. 2009. Concise Encyclopedia of Pragmatics. Oxford: Elsevier. MacLaughlin, Dawn. 1996. Second Language Acquisition of English Reflexives: Is There Hope beyond Transfer. In Stringfellow, Andy et al. (eds.), Proceedings of the $20^{\text {th }}$ Annual Boston University Conference on Language Development, 453-464. Somerville, Massachusetts: Cascadilla Press.

MacLaughlin, Dawn. 1998. The Acquisition of the Morphosyntax of English Reflexives by Non-Native Speakers. In Beck, Maria-Luise (ed.), Morphology and Its Interfaces in Second Language Knowledge, 195-226. Amsterdam: John Benjamins Publishing.

MacWhinney, Brian; Pléh, Csaba \& Bates, Elizabeth. 1985. The development of sentence interpretation in Hungarian. Cognitive Psychology 17: 178-209.

Pearson, Barbara Zurer \& Roeper Thomas. 2004. Learnability and triggers: Obligatory versus optional triggers for the passive in two dialects of English and in language impairment. In Brugos, Alejna, Micciulla, Linnea \& Smith, Christine (eds.), BUCLD 28, The proceedings of the $28^{\text {th }}$ Annual Boston University Conference on Language Development, 447-460. Somerville, MA: Cascadilla Press.

Pinker, Steven; Lebeaux, David S. \& Frost, Loren. 1987. Productivity and constraints in the acquisition of the passive: Cognition 26: 195-267.

Schachter, Jacquelyn. 1996. Maturation and the issue of Universal Grammar in second language acquisition. In Ritchie, William \& Bhatia, Tej (eds.), Handbook of Second Language Acquisition, 159-193. San Diego: Academic Press.

Schwartz, Bonnie. 1998. On two hypotheses of transfer in SLA: minimal trees and absolute L1 influence. In Flynn, Susan; Martohardjono, Gita and O’Neil, Wayne (eds.), The generative study of SLA, 35-59. Mahwah, NJ: Lawrence Erlbaum.

Siewierska, Anna. 1984. The Passive. A Comparative Linguistic Analysis. London: Croom Helm.

Tankó, Enikő. 2011. The Acquisition of the English Passive Construction by L1 Speakers of Hungarian. PhD thesis. Bucharest: University of Bucharest.

Tóth, Ildikó. 2000. Va- and ván- Participles in Hungarian. In Alberti, Gábor and Kenesei, István (eds.), Papers from the Pécs Conference. Approaches to Hungarian 7: 237-256. Szeged: JATE Press.

Wanner, Anja. 2009. Deconstructing the English Passive. Berlin: Mouton de Gruyter.

White, Lydia. 2003. Second Language Acquisition and Universal Grammar. Cambridge: CUP. 